\title{
The world in the head: aplicação do modelo de Klaus Bruhn Jensen ao discurso dos media baianos
}

Itania Maria Mota Gomes e Ana Cristina M. Spannenberg*

\section{RESUMO}

O trabalho propõe-se a apresentar a matriz interpretativa proposta por Klaus Bruhn Jensen para a análise dos super-temas e explorar as conseqüências de sua aplicação à análise e interpretação de programas jornalísticos diários. Consideramos que o modelo, originalmente desenvolvido para a análise da recepção, também pode ser utilizado na análise e interpretação de programas jornalísticos, oferecendo subsídios para entendermos melhor o encontro entre os meios e seus receptores. Assim, o presente trabalho propõe-se a fazer um exercício de aplicabilidade do modelo em dois telejornais transmitidos em sinal aberto para a cidade de Salvador - Bahia, no Brasil.

\section{A B STRACT}

This works intends to present the interpretative matrix proposed by Klaus Bruhn Jensen for the analysis of super-themes. Also, it intends to explore the consequences of the model's applicability to the analysis and interpretation of daily journalism programs. We consider that this model, originally developed for reception analysis, can also be used for the interpetation and analysis of journalism programs, offering support for a better understanding of the meeting between the media and its receptors. Thus, the work aims to apply this model in two journalism programs broadcasted in open signal for the Salvador city.

\footnotetext{
*Itania Maria Mota Gomes, Ph.D, UFBA; Ana Cristina M. Spannenberg, mestranda, UFBA.
} 


\section{The world in the head: aplicação do modelo de Klaus Bruhn Jensen ao discurso dos media baianos}

Com o intuito de compreender o modo como espectadores de televisão em diversos países do mundo produzem um sentido local para as notícias globais, o pesquisador dinamarquês Klaus Bruhn Jensen coordenou o projeto News of the world, iniciado em 1989 e concluído em 1997. Nele, pesquisadores de sete países (Bielo Rússia, Dinamarca, Índia, Israel, Itália, México e Estados Unidos) trabalharam de modo coordenado, utilizando a análise qualitativa de recepção, para tentar descobrir o modo como os receptores entendem e interpretam as notícias com base nas suas vidas cotidianas. $\mathrm{O}$ objetivo do projeto era analisar as estruturas de compreensão com que uma pequena amostra de telespectadores em sete diferentes países interpreta os acontecimentos nacionais e estrangeiros reportados pelos telejornais de um dia específico, 11 de maio de 1993. Uma das principais questões do autor é compreender como as audiências empregam as notícias como fonte para a atuação política no dia-a-dia. ${ }^{1} \mathrm{~A}$ análise de recepção foi precedida da análise de conteúdo dos programas nacionais de notícia em cada país durante a semana de 05 a 11 de maio de 1993.

A análise de recepção é compreendida por Jensen como uma metodologia interdisciplinar que acolhe contribuições das ciências humanas, particularmente daquelas que se dedicaram à análise dos textos mediáticos, e das análises sociológicas da audiência. ${ }^{2}$ Nesse sentido, metodologias de recepção produzem, ou devem produzir, uma análise comparativa dos discursos dos meios e dos discursos da audiência, tal como aparecem documentados em entrevistas, notas de observações diretas, diários de campo.

O presente trabalho tem um duplo objetivo. Primeiro, apresentar a matriz interpretativa proposta por Jensen para a análise dos super-temas e explorar as conseqüências de sua aplicação à análise e interpretação de programas jornalísticos diários, na perspectiva da representação da cultura. Pretendemos, assim, explorar a produtividade da aplicação de uma mesma matriz interpretativa tanto aos processos de apropriação por parte da audiência quanto aos processos de representação da cultura efetivados pelos media. Nossa hipótese é de que esse procedimento teórico-metodológico poderá nos oferecer pistas para analisar o encontro entre media e seus receptores e servir de algumas garantias epistemológicas no processo de investigação da recepção. Segundo, apresentar a comunidade científica as contribuições deste que entendemos seja um dos investigadores contemporâneos mais interessantes para a discussão sobre recepção, por seu esforço de articulação entre as investigações sociológicas e as investigações sobre o texto. ${ }^{3}$ 
Assim, o presente trabalho propõe-se a fazer um exercício de aplicabilidade do modelo em dois telejornais transmitidos em sinal aberto para a cidade de Salvador. A amostra reunirá cinco edições dos telejornais BA TV e Aratu Notícias Segunda Edição, respectivamente da TV Bahia, afiliada da Rede Globo, e da TV Aratu, afiliada do SBT, entre os dias 07 a 11 de janeiro de 2002. O trabalho está estruturado em três partes. Começamos com uma breve apresentação do modelo proposto por Jensen, explicando cada uma das dimensões que compõem a matriz interpretativa. Em um segundo momento, faremos a análise, primeiro relatando um pouco das notícias que marcam a semana escolhida, depois traçando um breve perfil das emissoras escolhidas e detendo-nos mais à aplicação do modelo proposto aos telejornais BA TV e Aratu Notícias, nessa ordem. Por fim, concluímos esse texto com considerações sobre a aplicabilidade do modelo à análise dos programas e sobre os ganhos teórico-metodológicos vislumbrados.

\section{Modelo The world in the head}

A principal categoria de análise utilizada pelos pesquisadores de News of the world foi o super-tema. ${ }^{4}$ Segundo Jensen, supertemas são construções temáticas através das quais os telespectadores podem estabelecer relações entre o mundo de suas vidas cotidianas e o mundo tal como representado nos relatos das notícias televisivas. Supertemas podem ser vistos como mediadores entre os espectadores e o relato por traduzir uma realidade que aparece complexa e distante em termos simples, gerais e pessoalmente compreensíveis (JENSEN, 1998, p.19) ${ }^{5}$

A partir da análise dos supertemas manifestos no discurso das famílias entrevistadas em cada um dos países, ${ }^{6}$ Jensen estabeleceu um modelo interpretativo chamado The world in the head. Isso é feito através da análise dos modos como os receptores apropriam-se das notícias e as traduzem para seu cotidiano, levando em conta quatro dimensões relacionadas, as dimensões de espaço, tempo, poder e identidade, que, segundo Jensen, endereçam de diferentes maneiras aspectos da organização social do tempo, do espaço, das relações interpessoais e das relações institucionais.

Após reunir as respostas dos entrevistados nos sete países, Jensen identifica a necessidade de "uma segunda ordem de análise dos supertemas para detectar princípios estruturais que podem unir ou dividir os grupos de entrevistados nacionais ao longo de dimensões analíticas similares" (JENSEN, 1998, p.165). O autor apresenta quatro dimensões para análise - espaço, tempo, poder e identidade - e propõe a configuração das dimensões na forma de um modelo. Segundo Jensen, as dimensões podem "indicar como as audiências dos modernos meios de massa articulam conhecimentos específicos e diferentes do espaço social, tempo, autoridade e identidade, em 
resposta a gêneros particulares dos media e com referência a seus contextos culturais" (ibidem, p.182).

A dimensão do espaço reúne o sentido de localização com relação a um espaço maior (no país, no mundo) e a percepção de proximidade ou não dos acontecimentos. Na pesquisa de Jensen ela pode ser percebida por dois aspectos dos discursos dos entrevistados: a noção de "segurança ontológica", com relação a proximidade de acontecimentos que possam afetar à família; e a noção de distância entre as notícias relatadas e o receptor, que dá a ele o sentido do seu lugar no mundo (cf. ibidem, p.165). O autor enfatiza que "essa dimensão refere-se ao que é simultaneamente um espaço mental e social, certamente não por absoluta distância geográfica, mas pela distância experimentada dos eventos" (ibidem, p.166).

A dimensão de poder, segunda apresentada pelo autor, indica as relações do indivíduo com a autoridade e é identificada na relação do indivíduo com as instâncias de poder já instituídas que afetam sua vida cotidiana. Elas procuram demarcar, entre os agentes presentes, quem possui autoridade e quem é destituído dela nas notícias. Conforme o autor, essa autoridade pode variar: nos países analisados na pesquisa, as instituições que detinham o poder podiam ser nacionais ou estrangeiras, religiosas ou seculares. Além disso, o sentido de impotência daqueles que não tinham autoridade podia ser causado pelo estado ou por inimigos particulares, pelo destino ou por ameaças ao indivíduo (cf. ibidem, 166).

90 A terceira dimensão proposta pelo autor é a de tempo. Essa dimensão foi introduzida por vários dos entrevistados como um meio de orientação em relação aos acontecimentos do dia-a-dia reportados nas notícias da TV. Jensen chama a atenção para essa dimensão pela qual os receptores recompõem a história, apresentada de forma fragmentada pelos telejornais, compensando essa característica dos meios e procurando dar "coerência" e "relevância" aos acontecimentos (cf. ibidem, 166).

Por fim, a dimensão de identidade refere-se à identidade cultural e individual dos telespectadores em relação com uma variedade de "outros", sendo esses outros tanto possíveis inimigos quanto aliados. Essa relação afeta diretamente as formas como o receptor interpreta as notícias a partir de sua realidade social. Esses "outros" constituem importantes pontos de referência para a compreensão que os entrevistados têm de si mesmos, já que seres humanos constroem sua identidade - socialmente, culturalmente e etnicamente - e, portanto, sua justificação para participação e ação na sociedade a partir de sua interação com outros e da perspectiva desses outros sobre ele. Diante disso, Jensen afirma que

a dimensão da identidade parece ter valor explanatório independente para uma compreensão da construção da realidade social do entrevistado já que ela serve para identificar aliados, 
valores e metas para a ação que possibilitam o verdadeiro processo de tornar-se um agente social em relação às outras dimensões de poder, espaço e tempo (ibidem, p.167).

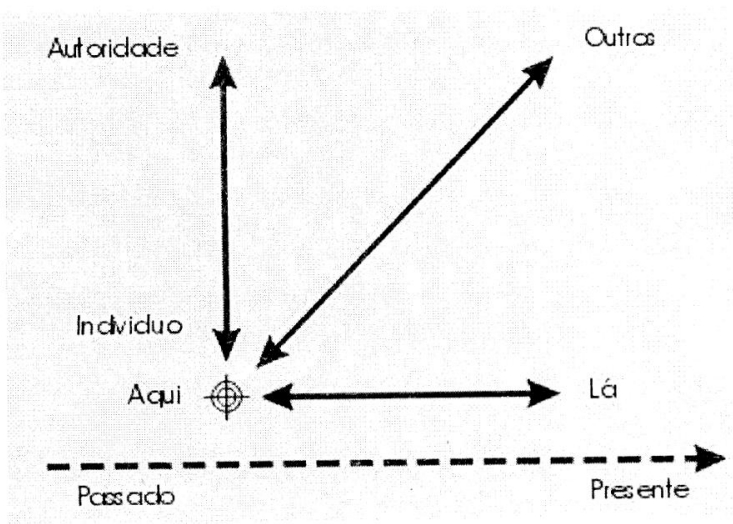

A matriz interpretativa que aparece acima é denominada de modelo The world in the head (cf. ibidem, p.168). Nela, a dimensão da identidade se constrói, ao longo do tempo, na relação com o poder e o espaço, já que nos tornamos nós mesmos em relação com a nossa estrutura social (poder) e com o resto do mundo (espaço).

\section{Análise dos telejornais}

Nosso propósito, a seguir, será aplicar a matriz interpretativa à análise de dois telejornais baianos, tentando perceber como as quatro dimensões são propostas aos seus receptores. Na semana analisada, de 07 a 11 de janeiro de 2002, foram produzidas pelo BA TV e pelo Aratu Notícias Segunda Edição um total de 74 e 69 matérias, respectivamente. Nessa soma estão incluídos todos os formatos de notícias, das matérias e notas, simples ou cobertas, passando por reportagens, entrevistas, stand up até chamadas para outros blocos.

A principal notícia foi a ameaça de greve da Polícia Militar de Salvador, que foi anunciada apenas como nota na edição de segunda-feira (07/01/2002), foi ampliada e tratada com mais tempo e aprofundamento na edição de terçafeira (08/01/2002), quando os conflitos se intensificaram, e recebeu menções durante a edição de quarta-feira (09/01/2002). A notícia teve grande repercussão, principalmente pela ameaça que a greve da polícia trazia, devido a uma ocorrência efetiva de greve seis meses antes, com graves episódios de violência e saques que receberam cobertura nacional pelas emissoras de TV. 
Além dela, também foram destaques as chuvas que atingiram a cidade de Salvador e diversos municípios no interior do estado, causando algumas mortes e deixando muitas pessoas desabrigadas ( 07 e 08/01/2002); o início da fiscalização aos postos de gasolina da capital ( 09,10 e 11/01/2002); e o conflito entre indígenas e fazendeiros no interior do estado (10 e 11/01/2002). Outro fato que recebeu grande repercussão nos dois telejornais foi a visita de 200 turistas israelenses à cidade de Salvador, pela primeira vez em um vôo direto fretado (08 e 09/01/2002).

\subsection{Telejornal BA TV}

O BA TV é o telejornal noturno da Rede Bahia, afiliada da Rede Globo. A rede mantém seis retransmissoras, além da sede em Salvador, localizadas nas cidades de Itabuna, Vitória da Conquista, Feira de Santana, Juazeiro e Barreiras. O sinal é transmitido para a Região Metropolitana de Salvador e mais 221 municípios, atingindo aproximadamente 1,4 milhões de domicílios e 7 milhões de espectadores. $O$ telejornal analisado faz parte da programação jornalística da rede e é transmitido às 19 horas, sempre em três blocos, de segunda a sábado.

A dimensão de espaço é uma das que recebe maior destaque no BA TV, onde se pode perceber de forma bem definida o "aqui" e o "lá". As notícias apresentadas na semana pesquisada separam claramente o que é "da Bahia" dos demais lugares citados, sejam eles outros estados do Brasil ou outros países. No texto, tanto a apresentadora quanto os repórteres utilizam "Bahia" ao referir-se ao estado e "Salvador" ao referir-se à capital, o que, como veremos mais adiante, não ocorre no outro telejornal analisado. A cidade de Salvador recebe maior ênfase e destaque jornalístico, porém por um viés abertamente turístico. Por esse motivo, o telejornal procura destacar o "aqui" de Salvador como um lugar seguro, não ameaçador.

Outro ponto do "aqui" que é posto em relevo, principalmente quando confrontado com os outros lugares é o exotismo, as diferenças culturais que, segundo o discurso turístico do BA TV, é cheio de "delícias" e "prazeres". Nesse aspecto, é interessante observar como a emissora Rede Bahia lida com a questão da identidade, a partir da dimensão do espaço. A ênfase na cidade de Salvador acolhe, na representação que dela se faz no BA TV, por exemplo, mas também em vários programas produzidos localmente, características do Recôncavo Baiano (região que representa, com sua formação a partir da lavoura açucareira, a mais forte contribuição negra no estado), com destaque para aspectos referentes à culinária, à dança e à música, à religião, à "simpatia do povo baiano" e a "beleza da mistura de raças", enfim, ao sincretismo e mestiçagem. Nas representações do BA TV, por exemplo, o olhar do "nós" e o olhar do "outro" se associam de modo muito peculiar através da ênfase ao turismo e do apelo à identidade baiana. Por um lado, a emissora pauta o 
telejornal e constrói suas representações de Salvador e dos baianos a partir do interesse em mostrar para os baianos por que o estrangeiro valoriza essa terra - e com isso, dizer ao baiano como ele deve representar a si mesmo para o turista (um povo alegre, hospitaleiro, festeiro e criativo) - e mostrar ao estrangeiro, turista à procura de programação para usufruir a cidade, o que ele pode fazer para melhor desfrutar da "capital da alegria" e da hospitalidade baiana. Assim se explica que um telejornal baiano, ao falar para o baiano, represente Salvador e a própria "baianidade" da perspectiva de suas características exóticas, evidenciadas, no discurso do BA TV. ${ }^{7}$

A representação do estado da Bahia como um todo pode ser percebida nas matérias referentes aos prejuízos causados pelas chuvas (07 e 08/01/ 2002), onde o telejornal apresenta a situação em diversas cidades do interior e na capital. Essa característica pode ser explicada levando em consideração a capacidade técnica que a Rede Bahia possui, pelo número de sucursais no interior do estado, que permite uma cobertura mais abrangente. Assim, o "aqui" apresentado no material analisado envolve uma área maior que apenas Salvador, permitindo que os textos mencionem a capital (em matérias sobre turismo, por exemplo, nos dias 08 e 09/01/2002) e o interior de formas distintas e não simplesmente com a generalização "Bahia".

A maioria das matérias analisadas destacava a cidade de Salvador, o que possivelmente decorre do período em que foram feitas, considerado alta temporada para o turismo. Em parte por esse motivo, em parte pela instabilidade causada na semana com a ameaça de greve da polícia militar, a grande ênfase do "aqui" é colocada na segurança da cidade. Com esse objetivo encontramos matérias sobre a reação de populares e turistas à ameaça de greve (08/01/2002) e sobre o intenso policiamento nas ruas (09/01/2002), além de diversas declarações de autoridades civis e militares sobre a contenção do movimento grevista inclusas nas matérias que repercutem o fato.

Ao contrário do "aqui" oferecido pelo BA TV, que envolve o estado da Bahia como um todo e a capital, Salvador, de modo mais específico, o "lá" não é muito definido. Algumas menções a outros estados do Brasil são feitas em matérias esportivas, sobre contratação de atletas de outros locais (08 e 09/01/ 2002); em notícias sobre o preço da gasolina em diversos locais do Brasil (09/ 01/2002); e em visitas de turistas de São Paulo à Igreja do Bom Fim, dentro dos preparativos para a festa (10/01/2002). Outros países são mencionados em duas situações: na visita de turistas israelenses (08 e 09/01/2002) e na preparação do boxeador Popó para sua luta, nos Estados Unidos (11/01/ 2002), de onde o atleta fala com a família, em Salvador. O "lá" é visto sempre em referência ao "aqui", ou seja, os outros lugares são mencionados para explicar situações que ocorrem em Salvador ou como um ponto de partida, sendo "aqui" o ponto de chegada. 
O tempo é uma dimensão fundamental a ser analisada, particularmente em relação ao jornalismo. No caso dos telejornais analisados, verificamos uma forte ênfase no presente. Alguns marcos temporais identificados funcionam para situar o telespectador sobre o "agora" da notícia (horário e dia do acontecimento narrado) ou sobre fatos futuros (chamadas para telejornal do dia seguinte, informações de serviço). Em poucos momentos o passado é convocado e, quando isso acontece, sua intenção é explicar o conflito presente, geralmente apresentando uma história crescente de conflitos.

Apenas algumas menções ao passado são encontradas na amostra do BA TV: o aumento no valor da cesta básica é noticiado em comparação com o mesmo período do ano anterior (07/01/2002); a ameaça de greve da polícia faz lembrar a greve real que ocorreu meses antes (08/01/2002); e o conflito entre fazendeiros e índios no interior do estado, que acontece há 14 anos (10 e 11/01/2002). Somente essas matérias buscam uma referência histórica, porém a grande maioria baseia-se apenas no "agora" para sua explicação.

Aqui há duas questões que queremos pôr em destaque. A primeira delas é o modo como o jornalismo se relaciona com a cultura do efêmero ou do presente.$^{8} \mathrm{O}$ jornalismo, em suas diversas modulações, obedece à mesma lógica da indústria cultural: ele é feito para ser consumido, para divertir e, nessa perspectiva, contribui para o processo de desencaixe das relações sociais (ver Giddens, 1991), funcionando como um "mecanismo de realimentação do processo atual de autonomização positiva do presente" 94 (Gomes, 1995, p.24).

A segunda questão diz respeito às possibilidades que a análise da dimensão do tempo traz para a investigação do jornalismo televisivo como um gênero televisivo. Nossa aposta é de que a dimensão do tempo pode ser uma das chaves para interpretação e análise dos diversos subgêneros que formam o jornalismo televisivo. Em se tratando de um telejornal diário, não nos surpreende a ênfase no presente, no dia-a-dia, próprio do discurso jornalístico factual. Entretanto, como a dimensão do tempo apareceria em outros sub-gêneros, o jornalismo temático? Como aparecem o passado, o presente e o futuro no documentário jornalístico, nos programas de entrevista? Acreditamos que esta pode se mostrar uma chave de análise bastante interessante para a compreensão do jornalismo televisivo.

A dimensão de poder, em quase todo telejornal BA TV, aparece através do "Estado protetor" ou "Estado provedor". A "autoridade" é conferida a todo agente que pode, de alguma forma, auxiliar, ajudar aqueles que estão desprovidos dela, portanto, vulneráveis. A partir disso, os personagens apresentados recebem a palavra para oferecer ou pedir ajuda, auxílio na solução de problemas que afetam o cotidiano da população. Para exemplificar, entre os vulneráveis podemos incluir os desabrigados e castigados pelas chuvas (07 e 08/01/2002), os intoxicados em restaurante universitário de Feira de 
Santana (09/01/2002), os consumidores que reclamam pelo preço da gasolina (11/01/2002) e os calouros de Medicina Veterinária que são vítimas de trote (11/01/2202). Em todas essas situações, os personagens aparecem como vítimas de algum tipo de violência e o telejornal oferece espaço para que eles reclamem e peçam soluções às autoridades responsáveis.

As autoridades, em contrapartida, têm voz de destaque no BA TV e são representadas como todos aqueles que podem auxiliar de alguma forma na solução dos problemas. Entre elas, encontram-se: técnicos da defesa civil (08 e 09/01/2002), o funcionário da Funai que socorre o vaqueiro agredido pelos índios (10/01/2002), a direção da Faculdade de Medicina Veterinária da Universidade Federal da Bahia que condena o trote (11/01/2002) e os fiscais da Prefeitura de Salvador, da Agência Nacional de Petróleo e a figura política de Antônio Carlos Magalhães que toma a palavra para defender os consumidores baianos (11/01/2002). Em todos os casos, a noção de autoridade é representada a partir do poder instituído, aquele que se faz representar nas diversas instituições do poder municipal, estadual ou federal. Mas nada pode ser mais ilustrativo que a matéria em que ACM aparece para falar como baiano, ou melhor dito, como o pai/protetor ${ }^{9}$ de todos os baianos contra os abusos do cartel de combustíveis.

Entretanto, apesar desses diversos personagens a quem é conferida vulnerabilidade ou autoridade para ajudar, um conflito principal destaca-se na semana analisada: a ameaça de greve da Polícia Militar de Salvador. Nesse episódio que ocupou espaço em, pelo menos, três telejornais (07, 08 e 09/01/ 2002), vemos claramente a distinção entre aqueles que estão vulneráveis - a população - e aqueles apresentados como quem pode restaurar a segurança - autoridades como governador do Estado, secretária de Segurança Pública e chefes das polícias civil e militar. Enquetes com populares nas ruas $(08 / 01 /$ 2002) revelam a fragilidade da população e seu pedido de ajuda: "O policial tem que estar nas ruas protegendo o povo", afirmou uma mulher entrevistada no centro da cidade. Em resposta, diversas autoridades passaram pelas matérias do BA TV respondendo ao apelo e confirmando que a ameaça de greve estava sob controle e que os responsáveis já haviam sido punidos ( 08 e 09/01/2002). Nesse episódio aparece claramente a noção do Estado protetor e, também, a vinculação entre o BA TV e as políticas públicas municipais e estaduais para o turismo. No episódio da greve da PM, o estado intervém antes que a ameaça se concretize.

Finalizando, percebemos a dimensão de identidade, que demonstra a relação entre o "eu" idealizado pelo telejornal e os "outros", diferentes desse. O outro assume duas formas distintas no BA TV: por um lado ele é ameaçador, o que inclui todo aquele capaz de perturbar a ordem instituída e retirar a segurança do "eu"; por outro, ele é o diferente, que chega como amigo e traz benefícios. Ao outro ameaçador não é conferido direito à voz nos telejornais 
ou, quando isso acontece, nunca com reconhecimento e importância. Já ao outro amigo é oferecida a palavra para exaltar as características positivas do "eu" e do "aqui".

Entre as ameaças que são apresentadas na semana analisada do telejornal, encontram-se os policias que tentam convencer seus companheiros a iniciar uma greve e são presos (07/01/2002) e aqueles que, efetivamente, no dia seguinte começam o movimento (08/01/2002). Nesse caso, os grevistas até foram ouvidos, embora em número bem menor que as "autoridades" e sem receber crédito na tela. Nessa mesma condição estão também os indígenas que, no interior do estado, sitiam um local e fecham uma estrada, agredindo quem tenta passar por ela; os caminhoneiros que bloqueiam uma estrada entre Bahia e Piauí em protesto; o casal de traficantes preso transportando craque (todas em 10/01/2002); e ainda os "bandidos", como são chamados, mortos em tiroteio com a polícia por roubo de carro (11/01/2002).

Os outros amigos são os turistas que visitam Salvador. No material analisado destaca-se um grupo em especial: os 200 israelenses que chegam no primeiro vôo de Israel para Salvador e visitam lugares exóticos e diferentes da cidade (08 e 09/01/2002). Esse grupo recebe atenção dobrada do BA TV, que resulta em duas matérias em dias consecutivos. $O$ texto enfatiza a cultura diferente que os visitantes trazem, suas crenças e costumes, mas também apresenta os exotismos de Salvador e faz questão de registrar a surpresas dos turistas diante deles. Nas entrevistas, ressalta-se o elogio desses ao que a repórter chama de "boa terra", Salvador. Além dos israelenses também são mencionados turistas nas matérias sobre a festa na Igreja do Bom Fim (10/01/ 2002) e sobre o Farol Folia (11/01/2002), sempre como o diferente que se encanta com a capital baiana.

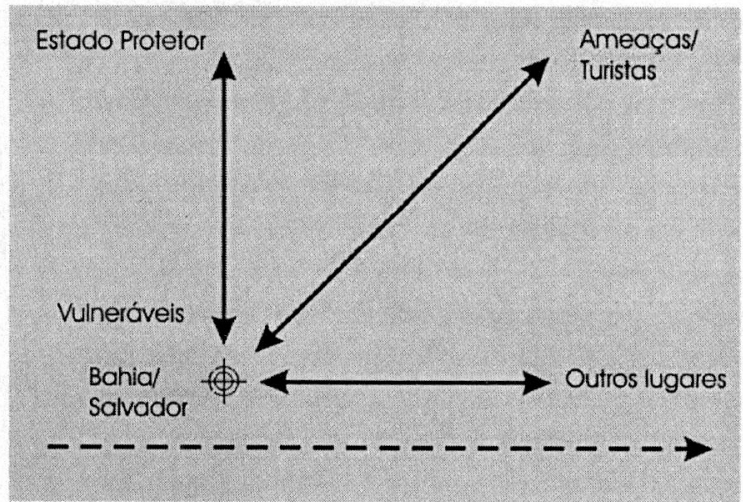




\subsection{Aratu Notícias}

A TV Aratu é afiliada do Sistema Brasileiro de Televisão (SBT) em Salvador. O seu sinal é transmitido para cerca de 80 municípios, alcançando um público de 6,2 milhões de espectadores. O Aratu Notícias Segunda Edição é o telejornal noturno da emissora, transmitido às 19 horas, em três blocos, de segunda a sábado.

No Aratu Noticias, a dimensão de espaço é delimitada entre Salvador, como o "aqui" e os outros lugares mencionados como o "lá". O que permite fazer essa distinção de forma bastante clara é a ênfase dada para eventos locais, com notícias produzidas por uma equipe de reportagem, enquanto os eventos que eram registrados fora de Salvador apareciam somente em notas simples, ou seja, texto do apresentador sem imagens. Assim, o "centro dos eventos" apresentados era a capital baiana, embora algumas vezes tratada apenas como "a Bahia", numa apropriação do macro pelo micro. Deve-se levar em consideração, porém, que os eventos de fora talvez tenham um tratamento diferenciado não pela sua pouca importância, mas por deficiências de ordem técnica.

Entre os exemplos que demonstram esse contraste, podemos citar a reportagem sobre as chuvas que mostra diversas imagens de Salvador - ruas alagadas, trânsito congestionado, acidentes, desabamentos - enquanto os danos causados no interior são apenas relatados oralmente pela apresentadora (07 e 08/01/2002). A única exceção em todas as edições analisadas é uma matéria previamente agendada, a cobertura da inauguração de uma barragem, a $900 \mathrm{~km}$ de Salvador (09/01/2002).

Quanto à imagem de Salvador, como no outro telejornal analisado, o destaque também está no aspecto turístico. É interessante ressaltar como, principalmente na matéria sobre os turistas israelenses, o texto utiliza Bahia para falar apenas da cidade de Salvador. A apresentadora abre a notícia com a frase: "Eles vieram do outro lado do mundo para conhecer os encantos da Bahia" e o texto do repórter prossegue falando sobre as belezas da capital. Aqui, a parte (capital) vale pelo todo (estado), o macro é incorporado pelo micro. Vale destacar que o grupo de turistas visitou apenas a capital da Bahia e não todo o Estado.

Os marcos temporais no Aratu Notícias são configurados de modo um tanto diferente do BA TV. Nas matérias analisadas, a ênfase se deu sobre o presente, mas tanto o presente quanto o passado aparecem de modo mais significativo que no BA TV. O Aratu Notícias mostrou maior preocupação com o futuro próximo - o Carnaval. Assim, em quatro das cinco edições analisadas o marco que norteia muitas das matérias é a festa do Carnaval. ${ }^{10}$ Muitas matérias são feitas para antecipar seus acontecimentos ou prevendo 
o que elas poderão ocasionar de modificações na situação atual. Não se pode afirmar que essa seja a única dimensão de tempo no telejornal, mas é, com certeza, a que registra maior número de ocorrências no período analisado.

As festas delimitam a principal notícia da semana: policiais tentam convencer colegas a promover greve durante o Carnaval (07 e 08/01/2002). Mas também aparecem em diversas matérias sobre os preparativos para 0 "Carnaval antecipado", chamado Farol Folia, que são feitas em quatro das cinco edições (única exceção é 10/01/2002), levantando diversos aspectos do acontecimento como o novo trajeto, os benefícios para comerciantes próximos, a procura por blocos e a insatisfação de comerciantes que serão obrigados a fechar suas portas.

Com referência a marcos temporais do passado, eles aparecem em poucas matérias e não possuem um contorno definido ou único. São percebidos apenas nas notícias sobre a construção da barragem, onde uma entrevistada conta como era a vida antes dela (09/01/2002); sobre a Festa do Bom Fim, com um pequeno relato sobre como ela começou (10/01/2002); e sobre o primeiro transplante de fígado da Bahia, onde a repórter fala sobre o período da operação e do tratamento, um mês antes (11/01/2002). Outra vez, aqui, aparece a dimensão de tempo como uma das mais importantes para a análise dos modos de configuração do jornalismo televisivo. Nesse caso, por exemplo, a análise da dimensão de tempo não contradiz a ênfase no presente, mas evidencia uma maior contextualização na abordagem jornalística dessa 98 emissora.

$\mathrm{Na}$ dimensão de poder encontramos uma situação muito parecida com a apresentada no BA TV, ou seja, aqueles que têm autoridade para auxiliar na manutenção da ordem e aqueles que estão, de alguma forma, ameaçados. Entretanto, o destaque maior é dado à violência, como em todo o telejornal da TV Aratu, e as vozes dos que estão sofrendo violência quase não são ouvidas. Aqui aparece de modo ainda mais forte a representação da autoridade através do poder instituído. Poderíamos então propor uma divisão entre "representantes oficiais" e "vulneráveis", o que parece espelhar melhor a situação apresentada, isso porque aqui a solução dos conflitos está exclusivamente na mão de autoridades constituídas oficialmente.

Os pares de autoridades e vulneráveis podem ser assim distribuídos, ao longo da semana analisada: fiscais da Agência Nacional de Petróleo que vão defender os direitos dos consumidores (07/01/2002); governador do Estado, secretária de Segurança Pública e comandantes das polícias civil e militar, que não permitem a concretização da greve que ameaça a população $(08 / 01 /$ 2002); e policiais que serão responsáveis pela segurança dos foliões que participam do Farol Folia (09/01/2002). Entretanto, é importante ressaltar novamente que somente nos dois primeiros episódios os vulneráveis foram ouvidos e, de qualquer forma, em número bastante reduzido. O próprio repórter 
e a apresentadora do jornal fazem o papel de mediadores, levando as reclamações e pedidos para as autoridades competentes.

A dimensão que mais se destaca no Aratu Notícias é a de identidade, demarcando bem a separação entre o "eu" e os "outros". O modo de representação é bastante semelhante ao que aparece no BA TV, mantendo uma grande proximidade no tratamento dispensado ao "outro" que é amigo e oferece benefícios. A diferença, porém, está no tratamento destinado ao que a TV Aratu apresenta como o "agressor": o outro não é apenas o que ameaça, mas o que efetivamente realiza um ato violento.

A esse tipo de outro causador de violência não é conferida a palavra em nenhum momento. Ao contrário, eles são apresentados com expressões pejorativas como "bandidos" e mostrados em cenas filmadas em delegacias ou em locais onde cometeram crimes. Entre os exemplos, diversos presos por assassinatos (07 e 08/01/2002), por assaltos (08,09 e 10/01/2002), por tráfico de drogas (10/01/2002) e por pedofilia (11/01/2002). A presença desses outros se registra em matérias da editoria de Polícia, bastante freqüentes no Aratu Notícias.

Já os turistas, os "outros amigos", são apresentados naquilo que têm de diferente em relação aos baianos - por exemplo, na dificuldade de dançar. Apenas uma matéria sobre turistas foi encontrada em toda a semana analisada e nela o repórter acompanha o passeio do grupo de israelenses que visita Salvador (09/01/2002). Destacam-se as reações que os turistas têm às "belezas da Bahia" e suas vozes são ouvidas para exaltar o que é local. Assim, esse tipo de outro, além de diferente, traz benefícios ao "eu" e elogia suas características. 


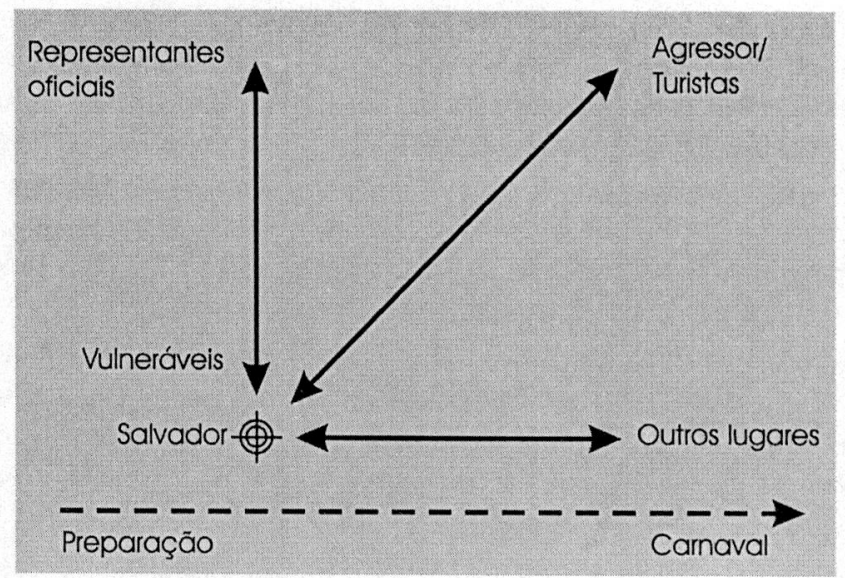

\section{Breves conclusões}

Entendemos que, apesar de todos os limites implicados nesta tentativa embrionária - a reduzida amostra, a impossibilidade de trazer ao mesmo tempo a investigação sobre a recepção desses telejornais analisados - a aplicação da matriz interpretativa proposta por Klaus Jensen para a interpretação dos supertemas à análise de uma amostra de telejornais mostrou-se produtiva. Em primeiro lugar, porque Jensen constrói um modelo que traz em causa tanto as formas de percepção, através das dimensões de tempo e espaço, quanto as questões da representação da cultura, tal como pensada por Stuart Hall (1997), através das dimensões de poder e identidade. Nesse sentido, quando aplicada à análise e interpretação de programas jornalísticos diários, a matriz nos oferece uma boa perspectiva de interpretação das representações da cultura construídas pelos telejornais.

Acreditamos que a aplicação de uma mesma matriz interpretativa tanto aos processos de apropriação por parte da audiência (modos como os receptores apropriam-se das notícias e as traduzem para seu cotidiano) quanto aos processos de representação da cultura efetivados pelos media pareceunos um procedimento teórico-metodológico que pode oferecer um enquadramento analítico interessante, porque permitiria levar em consideração uma mesma matriz e, assim, nos oferecer pistas para analisar o encontro entre media e seus receptores. Assim, são trazidas em causa as percepções que as dimensões de espaço, tempo, poder e identidade deixam transparecer sobre como o telejornal situa seu receptor, que visão de mundo ele tenta apresentar e quais os percursos que utiliza para fazer isso, favorecendo um roteiro de 
investigação precioso. Entretanto, consideramos que a análise dos telejornais com base no modelo The world in the head, embora tenha validade teórica, só poderá oferecer respostas efetivas ao objetivo do modelo, quando confrontada com a análise do discurso de seus receptores. Não desconsideramos, porém, que a aplicação da mesma matriz interpretativa às representações culturais construídas pelos media e às representações culturais produzidas pelos receptores a partir da sua relação com um produto mediático específico oferece-nos algumas garantias epistemológicas no processo de investigação da recepção, às vezes tão fluido.

Apesar da fluidez, entretanto, ainda acreditamos, como Jensen, que "es la polisemia de la recepción la que debe examinarse para poder valorar concretamente el poder relativo de los medios frente a sus audiencias, em vez de la polisemia de textos de los medios de comunicación" (JENSEN, 1992, p.99). Segundo Jensen as interpretações dos receptores podem ser "seletivas e até opostas" (ibidem, p.118) e, por esse motivo, somente uma análise do conteúdo dos meios não é suficiente para saber se esse "mundo" previsto ou oferecido pelos telejornais está realmente na mente dos telespectadores, como pretende o modelo The world in the head.

A própria matriz mostrou-se interessante, além disso, quando aplicada aos produtos jornalísticos televisivos, porque identificamos que, se melhor explorada, ela pode nos fornecer pistas para a investigação sobre os gêneros e sub-gêneros da programação televisiva, mostrando como cada um deles se constrói de modo diferenciado em relação às quatro dimensões. Por exemplo, consideramos que pode se mostrar bastante produtiva a investigação sobre o modo como cada um dos subgêneros do jornalismo televisivo lida com a dimensão de tempo e de espaço. Vimos, em relação aos telejornais diários, a forte ênfase no presente. Estamos reconhecendo que um gênero é um modo de situar a audiência televisiva em relação a um programa, em relação ao assunto nele tratado e em relação ao modo como o programa se destina ao seu público. Nessa perspectiva, gênero é uma estratégia de interação e investir numa abordagem dos gêneros televisivos pode significar ultrapassar a dicotomia entre análise do produto televisivo e análise dos contextos sociais de sua recepção.

\section{Bibliografia:}

GIDDENS, Anthony. As conseqüiências da Modernidade, São Paulo: Ed. Unesp, 1991.

GOMES, Itania Maria Mota. "O jornalismo e a percepção do tempo e do espaço nas sociedades contemporâneas" in Locus. Ciência, Tecnologia \& Cultura, n², Salvador: Uneb, 1995, 18-26.

HALL, Stuart (Ed.). Representation: cultural representations and signifying practices, London: Sage, 1997. 
HALL, Stuart. "Enconding/Deconding" In HALL, Stuart at alii. Culture, media, language. Londres : Hutchinson/CCCS-Birmingham, 1980.

JENSEN, Klaus Bruhn \& JANKOWSKI, Nicholas. Metodologias cualitativas de investigacion en comunicacion de masas (Trad. de Joan Soler) Barcelona: Bosch, 1993. (Colección Bosch Comunicación).

JENSEN, Klaus Bruhn \& ROSENGREN, Karl Erik. "Cinco tradiciones en busca del público" in DAYAN, Daneiel (Comp.). En busca del público. Recepción, televisión, medios, Barcelona: Ed. Gedisa, 1997, 335-370.

JENSEN, Klaus Bruhn. "La política del multisignificado - Noticias en la televisión, conciencia cotidiana y acción política" In OROZCO, Guillermo (comp.). Hablan los televidentes - Estudos de recepción en varios países. Cuadernos de Comunicación y praticas sociales, n. 4. PROIICOM/UIA. México: 1992.

JENSEN, Klaus Bruhn. "Media reception: qualitative traditions" In JENSEN, Klaus Bruhn (org). A Handbook of Media and Communication Research. Londres e Nova York : Routledge, 2002.

JENSEN, Klaus Bruhn. "News as social resource: a qualitative empirical study of the reception on danish television news", in European Journal of Communications, vol. 3, n. 3, 1988, p.275-301.

JENSEN, Klaus Bruhn. La semiótica social de la Comunicación de Masas, Barcelona, Bosch, 1997, (Colección Bosch Comunicación).

102 press, 1986.

JENSEN, Klaus Bruhn. News of the World. World cultures look at television news, Londres: Routledge, 1998.

MAFFESOLI, Michel. A conquista do presente, Rio de Janeiro: Rocco, 1984.

\section{Notas}

${ }^{1}$ A relação entre notícias televisivas, consciência cotidiana, ação política e democracia é objeto de interesse de Jensen desde os anos 80 , com a publicação de Making sense of the news, 1986.

${ }^{2}$ Klaus Bruhn Jensen e Karl Erik Rosengren entendem que há cinco tradições de investigação sobre a articulação entre os media e seus públicos: a investigação sobre os efeitos, a investigação sobre os usos e gratificações, o enfoque culturalista, a análise literária e as análises de recepção. Jensen \& Rosengren apontam Morley, Ang e Radway como aqueles que elaboraram as análises de recepção mais preocupadas em integrar as perspectivas sociológicas às perspectivas semióticas.

${ }^{3}$ As principais contribuições de Klaus Bruhn Jensen para a investigação em recepção, além de News of the world, encontram-se em JENSÉN, 1986, 1988, 1992, 1993, 1997, 2002; JENSEN \& JANKOWSKI, 1993; JENSEN \& ROSENGREN, 1997. 
${ }^{4} \mathrm{O}$ conceito de supertema foi apresentado pela primeira vez por Jensen no artigo "News as social resource: a qualitative empirical study of the reception on danish television news", publicado no European Journal of Communications, vol. 3, n. 3, 1988, p.275-301.

${ }^{5}$ Traduções realizadas pelas autoras a partir do original em inglês.

${ }^{6}$ Não é nosso objetivo aqui relatar o projeto coletivo de pesquisa News of the world ou os achados empíricos em cada um dos países. Nesse sentido, nosso interesse se direciona para a categoria de supertema e para a matriz interpretativa the world in the head.

${ }^{7}$ Nesse sentido, é interessante notar como a representação da cultura baiana e da identidade cultural no BA TV não se diferencia da representação construída pelos órgãos de divulgação e publicidade das agências de turismo do estado. Ver pesquisa realizada no período 2001/2003, com apoio do CNPq, quando nossa preocupação estava colocada no modo como a cultura baiana é construída - discursivamente e socialmente construída - pelos media, particularmente pela televisão. Levando em consideração, por um lado, a própria economia política dos meios de comunicação, na consideração de sua regulação através das políticas públicas (no caso da Bahia, é particularmente evidente a concentração dos meios de comunicação em torno de um ou dois grupos políticos e em torno de um número reduzido de empresas de comunicação), mas também - o que parece ser determinante de uma certa "construção da cultura baiana" - o modo como as políticas estaduais de cultura e de turismo (no Estado, nos últimos dez anos pelo menos, a vinculação entre esses dois campos, a cultura e o turismo, tem assumido a condução das políticas públicas para a área) se associam com o grupo político-econômico hegemônico no Estado de modo a representar a cultura baiana e a identidade cultural baiana para os próprios baianos e para fora da Bahia.

${ }^{8} \mathrm{~A}$ hipótese de que a mídia é responsável por instituir o primado do presente na vida social contemporânea está presente em vários autores que discutiram as relações entre mídia e pós-modernidade, como Michel Maffesoli, Jean Baudrillard, Gille Lipovetsky, Paul Virilio, Anthony Giddens. Nesses autores, a cultura de massa aparece inteiramente voltada para o presente, segundo Maffesoli (1984, p.210), triplamente: sua finalidade explícita reside no lazer imediato, trata-se sobretudo de divertir; para ela, o presente histórico é a medida de todas as coisas; ela é uma cultura sem rastro, sem futuro, é feita para existir no presente vivo.

${ }^{9}$ Chamamos a atenção para que a instituição política $\mathrm{ACM}$ se forjou na ênfase de que ele é o "painho", o 'pai protetor dos baianos', aquele que defende os interesses da terra onde quer que vá.

${ }^{10} \mathrm{~A}$ TV Aratu tem se posicionado entre as emissoras locais como a que oferece a maior cobertura do Carnaval baiano, com cobertura ao vivo 24 horas por dia, durante os oito dias da festa. Isso remonta ao tempo em que a 
TV Aratu era retransmissora da Rede Manchete, que, no início dos anos 90, perdeu para a Rede Globo os direitos de transmissão do Carnaval carioca e apostou na divulgação, em rede nacional, do Carnaval de Salvador. Mesmo quando passou à retransmissora do $\mathrm{SBT}$, a TV Aratu manteve a divulgação do Carnaval de rua de Salvador como estratégia de diferenciação entre as emissoras locais.

3. Interpretação 